\title{
Changes in Activity of Three Sulfurtransferases in Response to Exposure to Cadmium, Lead and Mercury Ions
}

\author{
Marta Kaczor-Kamińska, Piotr Sura, Maria Wróbel ${ }^{*}$ \\ Medical Biochemistry, Jagiellonian University Medical College, Kraków, Poland. \\ Email: ${ }^{*}$ mbwrobel@cyf-kr.edu.pl
}

Received April 17 ${ }^{\text {th }}, 2013$; revised May 16 ${ }^{\text {th }}, 2013$; accepted June $5^{\text {th }}, 2013$

Copyright (C) 2013 Marta Kaczor-Kamińska et al. This is an open access article distributed under the Creative Commons Attribution License, which permits unrestricted use, distribution, and reproduction in any medium, provided the original work is properly cited.

\begin{abstract}
Cadmium, lead and mercury are environmentally persistent toxicants that affect tissues and cellular components or exert an effect on generation of reactive oxygen species causing a decreased level of available antioxidant reserves. Sulfurtransferases are enzymes that are widespread in nature. Rhodanese, 3-mercaptopyruvate sulfurtransferase and $\gamma$-cystathionase play an important role in the metabolism of L-cysteine. Heavy metal ions can bind to -SH groups of cysteine residues in their active sites and, therefore, decrease the activity of these enzymes and result in changes in the level of sulfane sulfur-containing compounds, products of L-cysteine desulfuration. Changes in the activity of sulfurtransferases were investigated in the kidneys, heart, brain, liver and skeletal muscle of Marsh frogs (Pelophylax ridibundus) after 10 days of exposure to $\mathrm{Pb}\left(\mathrm{NO}_{3}\right)_{2}$ at the concentration of $28 \mathrm{mg} / \mathrm{L}$ and $\mathrm{CdCl}_{2}$ at the concentration of 40 $\mathrm{mg}$ or $80 \mathrm{mg} / \mathrm{L}$, and in Xenopus laevies tissues after 7 and 14 days of exposure to $\mathrm{HgCl}_{2}$ at the concentration of 1.353 $\mathrm{mg} / \mathrm{L}$. The investigated heavy metal ions have a tendency to inhibit the activity of sulfurtransferases and decrease the level of glutathione, what can result in oxidative stress and oxidation of cysteine $-\mathrm{SH}$ groups to $-\mathrm{SOH}$. This reversible oxidation and reduction of these redox sensitive groups can play a role in defenses against oxidative stress. Based on the presented results, one can surmise that also the expression of the three sulfurtransferases depends on heavy metal ions and/or some parameters of oxidative stress, what can explain the increase of the activity of MPST and CST in the kidney.
\end{abstract}

Keywords: Sulfurtransferases; Heavy Metal Ions; Oxidative Stress

\section{Introduction}

Environmental contamination is a growing problem around the world. One of the most important global issues is chronic, low-level exposure to heavy metals. Cadmium, lead and mercury are toxicants that cause neurological, hepatological, reproductive and gastrointestinal pathologies [1-4]. There are three main reasons of heavy metal toxicity: 1) direct interactions with proteins due to their high affinities for thiol-, histydyl-, carboxyl-groups, influencing their structure, catalytic and transport functions in cells; 2) stimulated generation of reactive oxygen species (ROS) that modify the antioxidant defense and increase oxidative stress; 3 ) displacement of essential cations from specific binding sites, causing major disruption of their function [5]. Lead is chemically very similar to calcium and it competes with or mimics the action of calcium [6]. Lead in picomolar concentrations can com-

"Corresponding author. pete for binding sites in the cerebellum for phosphokinase $\mathrm{C}$, causing inhibition of cellular respiration and alterations of calcium-based reactions and neuronal signaling [7].

The cellular targets for metal toxicity include such organs as the kidney, liver, heart, testicles, as well as immune and nervous systems [8-12]. Cadmium, lead and mercury demonstrate multi-directional toxicity [13]. It is also known that several transition metals, such as zinc, iron, copper, cobalt and manganese participate in the control of various metabolic and signaling pathways. However, in excess, heavy metal ions can break down mechanisms guarding cellular homeostasis by binding to protein sites other than those tailored for that purpose or by displacement of other metals from their natural binding sites [14]. Cadmium, lead and mercury (sulfhydryl-reactive metals) are particularly insidious and can affect a vast array of biochemical and nutritional processes $[6$, $15]$. 
Endogenous sulfur-containing compounds play an important role in numerous physiological processes in organisms, such as stabilization of protein structure, regulation of enzymatic activity, and they are engaged in redox reactions (glutathione, thioredoxine) [16]. There are two amino acids used in animals as a source of sulfur: methionine and cysteine. Cysteine is an intermediate for the synthesis of glutathione, taurine and sulfate [17]. Free sulfhydryl group present in cysteine are considered crucial for the biological functions of proteins [17]. Sulfurtransferases are enzymes widespread in nature. Rhodanese (thiosulfate sulfurtransferase, EC 2.8.1.1), 3-mercaptopyruvate sulfurtransferase (MPST, EC 2.8.1.2) and $\gamma$-cystathionase (CST, cystathionine $\gamma$-lyase, EC 4.4.1.1) play an important role in the metabolism of L-cysteine [18]. Rhodanese is an enzyme, which is responsible for transfer of sulfane sulfur atoms (atoms of sulfur bound only to other sulfur atoms and so having an oxidation state 0 or -1 ) from various donors to acceptors. MPST and CST catalyze formation of sulfane sulfur-containing compounds from cysteine [18]. The catalytic activity of these enzymes depends on cysteine residues in their active sites [16]. Pollutants and xenobiotics can bind to -SH groups and, therefore, decrease the activity of enzymes and change the level of sulfane sulfur, a product of L-cysteine desulfuration. Thiol group of a redox active cysteine in the catalytic site of MPST and rhodanese may locally serve as an antioxidant. The sulfhydryl groups in the active site of the above-mentioned enzymes can bind heavy metal ions. Oxidation of these groups can inhibit the activity of the enzymes with redox-active cysteine in the active site, while reduction with thioredoxine or glutathione can recover the activity of these enzymes [16].

In biological systems, heavy metal ions mediate reactions in which ROS are produced (e.g. Fenton reaction) and in this way they are a direct cause of increased lipid peroxidation, modification of protein structure and protein functions and DNA damage $[11,14]$. The level of reactive oxygen species increases in the presence of heavy metal ions in tissues. The effect of heavy metal ions depends on the time of exposure and type of tissue $[8,9$, $11,12]$. The aim of the paper is to present the effect of cadmium, lead and mercury on the activity of three sulfurtransferases containing - SH groups in their active sites, together with changes in sulfane sulfur, cysteine and glutathione levels in frog tissues.

\section{Materials and Methods}

\subsection{Animals}

Thirty nine mature frogs Pelophylax ridibundus of both sexes were collected in the vicinity of Krakow (southern Poland) and were placed for 1 week in plastic aquaria with dechlorinated tap water. The animals were kept at room temperature with a natural day/night rhythm. After acclimatization, they were used in two experiments. The frogs were divided into the control group - not exposed to heavy metal ions, and the experimental groups kept in water containing $40 \mathrm{mg}$ or $80 \mathrm{mg}$ of cadmium chloride per one liter of water for $96 \mathrm{~h}$ or $240 \mathrm{~h}$, or in water containing lead nitrate $\mathrm{Pb}\left(\mathrm{NO}_{3}\right)_{2}$ at the concentration of 28 $\mathrm{mg} / \mathrm{L}$ for 10 days. Water was changed every $24 \mathrm{~h}$ in order to keep a stable level of heavy metal ions. The frogs absorbed heavy metal ions from the contaminated water through their highly permeable skin.

Twenty-three mature frogs Xenopus laevis of both sexes obtained from private breeding were divided into three groups: the control group - kept in clean dechlorinated water for 7 or 14 days, the experimental groupskept in water containing $1.353 \mathrm{mg}$ mercury chloride per one liter of water for 7 days or for 14 days.

The licenses were obtained from the Local Ethics Commission (43/OP/2005) and the Polish Ministry of Environment to perform studies on a protected species (ref. No: DOPogiz-4200/II-06/5453/05/aj).

\subsection{Tissue Collection}

After a determined time of exposure, the frogs were decapitated and the spinal cord was pitched. For biochemical determinations, the brain, liver, heart, kidney and muscle from the thigh were excised. The tissues were washed out in cold saline, immediately frozen in liquid nitrogen and kept at $-80^{\circ} \mathrm{C}$ for further use. For analysis, the tissues were homogenized in four volumes of $0.1 \mathrm{M}$ phosphate buffer $(\mathrm{pH}=7.5)$ and centrifuged at $1600 \mathrm{~g}$ for $5 \mathrm{~min}$. The supernatant was used for the determination of enzyme activities and sulfane sulfur level.

\subsection{Methods}

The MPST activity was assayed according to the method of Valentine and Frankenfeld (1974) [19] with some modifications described by Wróbel et al. (2004) [20]. The enzyme units were defined as nmols of pyruvate formed during $1 \mathrm{~min}$ incubation at $37^{\circ} \mathrm{C}$ per $1 \mathrm{mg}$ of protein. The rhodanese activity was assayed by the Sörbo method (1955) [21]. The assays were carried out according to the procedure described by Wróbel et al. (2004) [20]. The enzyme units were defined as $\mu$ moles of $\mathrm{SCN}^{-}$, which formed during $1 \mathrm{~min}$ incubation at $20^{\circ} \mathrm{C}$ per $1 \mathrm{mg}$ of protein. The $\gamma$-cystathionase activity was determined according to Matsuo and Greenberg (1958) [22] with the modification described by Czubak et al. (2002) [23]. The activity of cystathionine was expressed as nmole of 2-ketobutyrate formed during $1 \mathrm{~min}$ incubation at $37^{\circ} \mathrm{C}$ per 1 mg protein. Sulfane sulfur was determined by the method of Wood (1987) [24], based on cold cyanosis and colorimetric detection of ferric thiocyanate complex ion. The 
level of sulfane sulfur was expressed as nmole per $1 \mathrm{mg}$ protein. Protein was determined by the method of Lowry et al. (1955) [25] using crystalline bovine serum albumin as a standard. The RP-HPLC method of Dominick et al. (2001) [26] with the modification described by Wróbel et al. (2009) [27] was used to determine the level of reduced (GSH) and oxidized form (GSSG) of glutathione, cysteine and cystine. Standard curves were generated in the supernatant obtained from tissue homogenates in the range from 13 to $75 \mathrm{nmol}$ of each compound per $\mathrm{ml}$.

Cadmium content was determined in $30 \mu \mathrm{m}$ thick cryostat sections, lyophilized in the Edwards apparatus following mounting and subsequent covering with a carbon powder layer. The content of the element was calculated based on the EDS spectrum (energy dispersion spectrum) obtained by a JED JSH 5410 scanning microscope at the $20 \mathrm{kV}$ voltage and using an EDS detector Voyager 3100 manufactured by Noran. EDS spectrum presented the number of counts for elements versus energy. The results were expressed as millimoles per kilogram of dry mass, the average value \pm SD (standard deviation) for cryostat sections from each tissue. The mercury and lead content in a tissue sample was determined using $\mathrm{XRF}-\mathrm{X}$-ray fluorescence spectroscopy [28]. Events of characteristic energy for lead and mercury were counted. The results were compared to a standard curve for lead and mercury, respectively, and were expressed as milligram per kilogram of dry mass of tissue.

The statistical significance of differences between the experimental group and the controls were determined using the Student's t-test. The differences were regarded as significant at $\mathrm{p}<0.05$.

\section{Results and Discussion}

\subsection{Heavy Metal Accumulation in Frog Tissues}

Figure 1 shows accumulation of heavy metal ions in the liver, kidney, brain and testicles of the frogs exposed to $80 \mathrm{mg} \mathrm{CdCl} / 1$ (10 days), $28 \mathrm{mg} \mathrm{Pb}\left(\mathrm{NO}_{3}\right)_{2} / 1$ (10 days) and $1.353 \mathrm{mg} \mathrm{HgCl} / 1$ (14 days) in water. It can be ob- served that cadmium had a tendency to accumulate mainly in the testicle and mercury in the kidney. In the experimental group (exposure to cadmium), the concentration of that toxicant in the testicle was 45 times higher as compared to the control group. In the kidney, after 14 days of exposure to mercury, the concentration of mercury had a value 98 times higher in comparison with the value obtained for the control group. Concentrations of lead in the liver, kidney, brain and testicle were 9.3; 9.1; 1.5 and 4.7 times higher in the experimental group in comparison with the controls. EDS method and XRF analysis confirmed heavy metal accumulation in the tissues of the investigated animals.

\subsection{Tissues Response to Exposure to Mercury, Lead and Cadmium}

\subsubsection{Brain}

The brain is very susceptible to oxidative stress because of its intensive oxygen metabolism. For this reason, it had to develop numerous mechanisms of protection in order to defend itself against ROS [29]. The brain exhibits a high activity of $\gamma$-glutamyltranspeptidase (GGTP) and cysteinylglycine dipeptidase, so it may utilize glutathione and cysteine (Cys) from the serum [29,30]. Cadmium, in each dose, caused an increase of GSH and sulfane sulfur levels and also an increase of rhodanese and MPST activity in the brain (Figures 2-4) [8]. The increase of the level of GSH can suggest tissue mobilization against the oxidative stress generated by cadmium. The opposite effect, diminished sulfane sulfur levels, was observed for lead (Figure 2) and mercury (Table 1) [8, $11,12]$. This may indicate higher cysteine utilization for GSH production - the pathway alternate to sulfane sulfur production. The activity levels of rhodanese and MPST were significantly diminished after 7 and 14 days of exposure to mercury (Table 1) in comparison to the control group [11]. Lead ions caused a significant decrease in CST activity (Figure 5) [12]. It can be supposed that both a diminished level of sulfane sulfur-containing com-

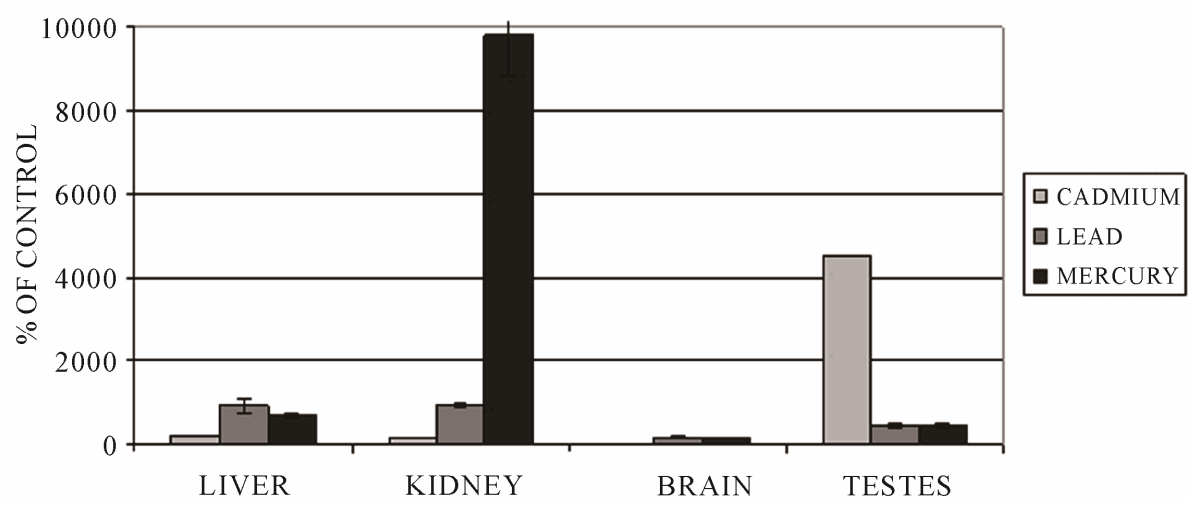

Figure 1. Accumulation of heavy metal ions in frog tissues. Cadmium in brain was not detected. 


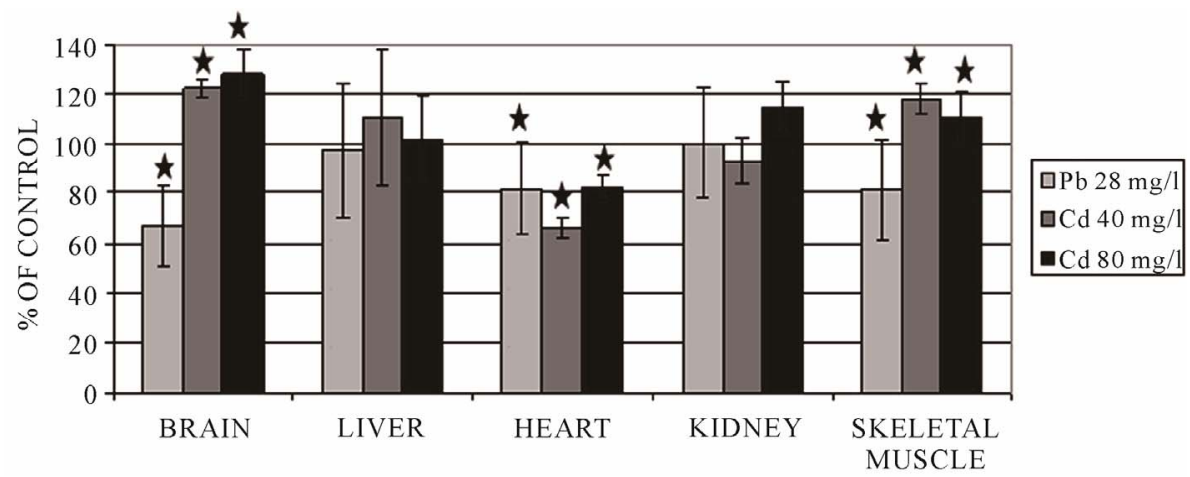

Figure 2. Changes of sulfane sulfur level in tissues of frogs after 10 -day exposure to heavy metal ions. ${ }^{*} \mathbf{p}<0.05$.

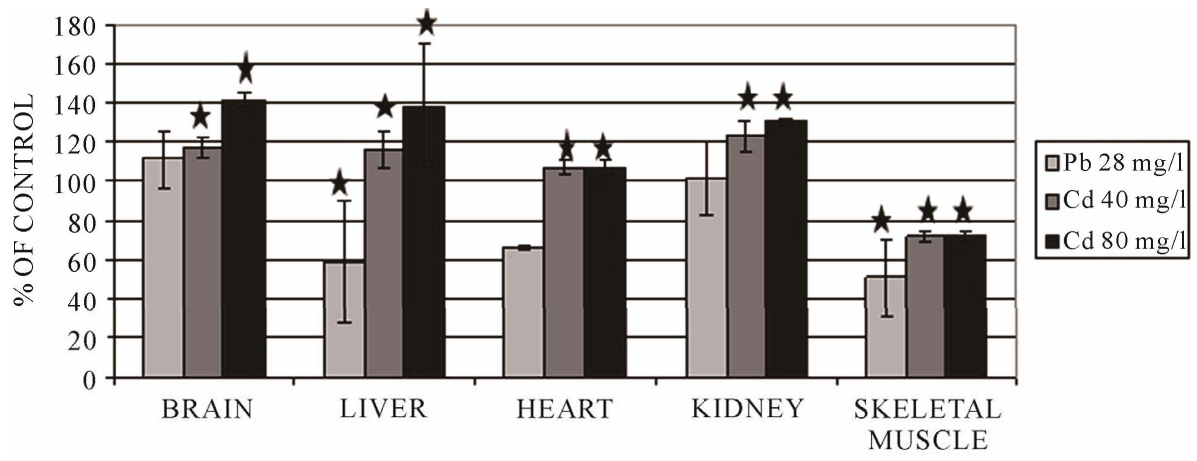

Figure 3. Changes of rhodanese activity in frog tissues after 10-day exposure to heavy metal ions. * $\mathrm{p}<0.05$.

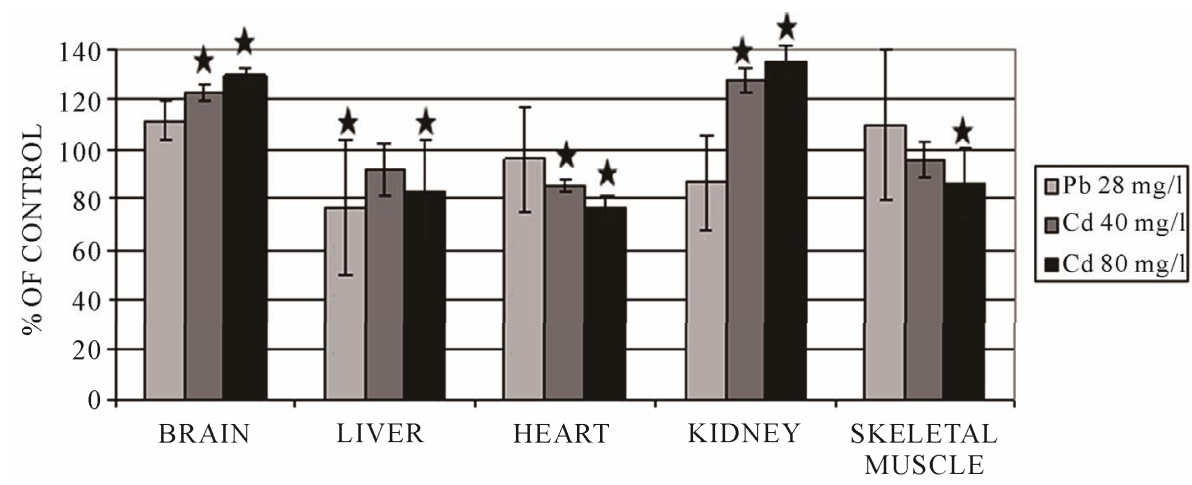

Figure 4. Changes of MPST activity in frog tissues after 10-day exposure to heavy metal ions. $\stackrel{*}{\mathrm{p}}<\mathbf{0 . 0 5}$.

pounds, substrates of rhodanese, and blocking of $-\mathrm{SH}$ group of rhodanese active site by mercury ions, which have a high affinity for sulfhydryl groups [2] can explain a decreased specific activity of rhodanese. In turn, a decreased level of sulfane sulfur can result from undetectable levels of cysteine in the brain exposed to lead ions in comparison with the control group (Table 2) [12]. A low GSH/GSSG ratio (Table 2) may suggest that the brain does not cope with the adverse impacts of lead ions. A double lowering of glutathione (Table 2) can be a consequence of blocking of low-molecular thiols by reactive lead ions [13].

In response to mercury ions, the level of reduced glutathione significantly increased after 7 days of exposure, whereas a decreased level was detected in the frogs from the 14-day group [11]. The ratio of GSH/GSSG reflected poorer conditions of the tissue within the scope of the maintenance of the cellular redox state-this ratio describes the antioxidative ability of the cell (Table 3) [11]. In case of enhanced generation of reactive oxygen species, sulfane sulfur-containing compounds can play a role as they have been already shown to have antioxidative properties [31]. Antioxidative processes are crucial in the brain because heavy metal ions can generate reactive free radicals and peroxides that contribute to peroxidation of unsaturated fatty acids [29] in phospholipids, which are a major component of brain tissue and trigger neurodegenerative processes $[30,32]$. 
Table 1. Concentration of protein and sulfurtransferases activity in $X$. laevis after exposure to mercury (1.353 $\mathrm{mg} / \mathrm{L}) \mathrm{for} 7$ and 14 days [11].

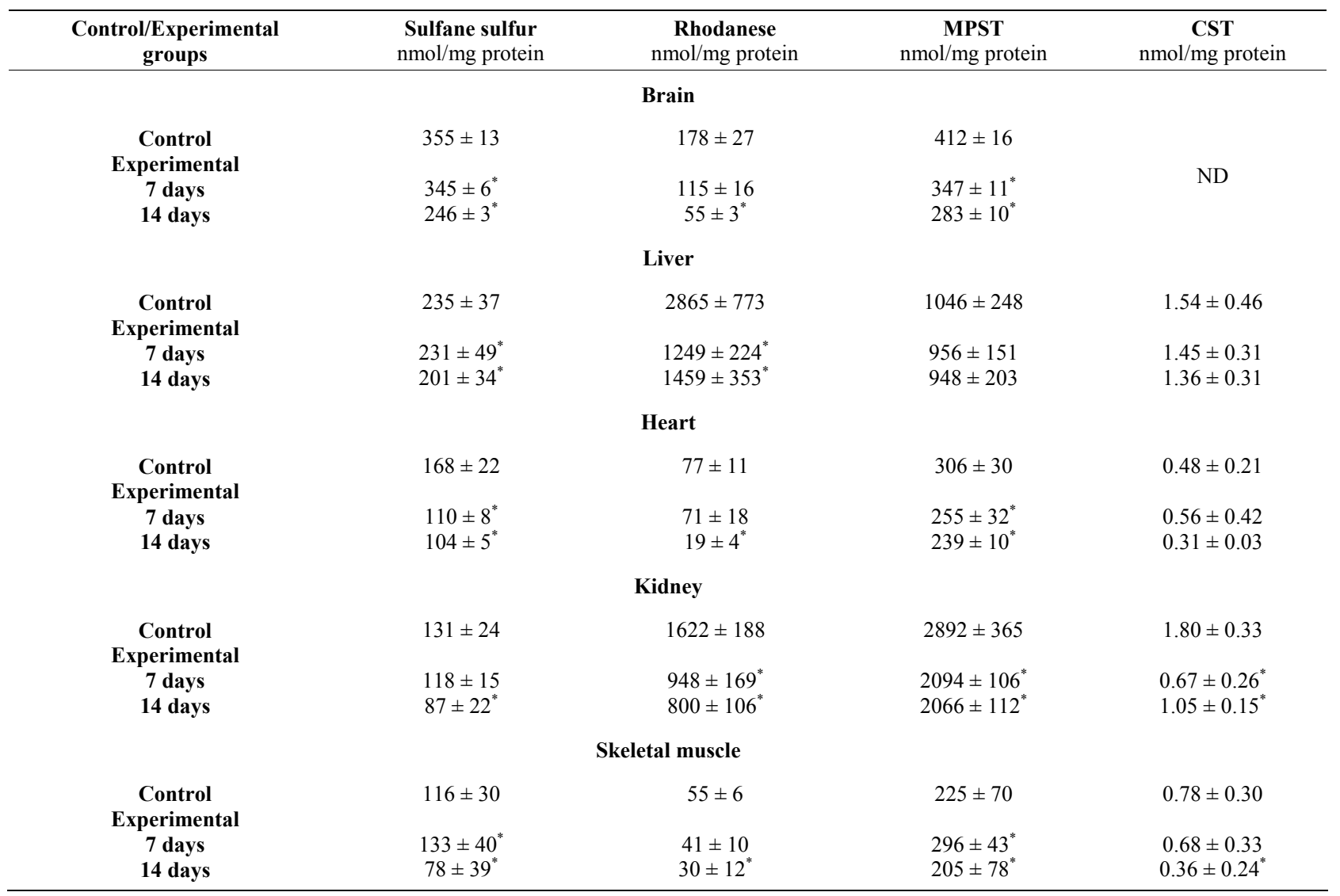

* $\mathrm{p}<0.05$; ND: non-detectable.

Table 2. The effect of lead on glutathione and cysteine levels in $P$. ridibundus [12].

\begin{tabular}{|c|c|c|c|c|}
\hline Group & $\begin{array}{l}\text { Total glutathione } \\
\text { nmol/mg protein }\end{array}$ & GSH/GSSG & $\begin{array}{c}\text { Total cysteine } \\
\text { nmol/mg protein }\end{array}$ & Cys/CSSC \\
\hline \multicolumn{5}{|c|}{ Brain } \\
\hline $\begin{array}{c}\text { Control } \\
\text { Experimental }\end{array}$ & $\begin{array}{c}209.2 \pm 73.2 \\
102.6 \pm 8.8\end{array}$ & $\begin{array}{c}0.8 \pm 0.02 \\
0.7 \pm 0.3\end{array}$ & $\begin{array}{c}5.7 \pm 4.6 \\
\mathrm{ND}\end{array}$ & $\begin{array}{l}\text { ND } \\
\text { ND }\end{array}$ \\
\hline \multicolumn{5}{|c|}{ Liver } \\
\hline $\begin{array}{c}\text { Control } \\
\text { Experimental }\end{array}$ & $\begin{array}{l}8.4 \pm 2.4 \\
6.4 \pm 2.7\end{array}$ & $\begin{array}{c}7.6 \pm 4.9 \\
10.8 \pm 8.3\end{array}$ & $\begin{array}{l}3.1 \pm 1.6 \\
4.3 \pm 2.7\end{array}$ & $\begin{array}{c}0.4 \pm 0.2 \\
\mathrm{ND}\end{array}$ \\
\hline \multicolumn{5}{|c|}{ Heart } \\
\hline $\begin{array}{c}\text { Control } \\
\text { Experimental }\end{array}$ & $\begin{array}{l}10.4 \pm 0.3 \\
25.2 \pm 2.2\end{array}$ & $\begin{array}{l}2.4 \pm 0.1 \\
4.5 \pm 0.2\end{array}$ & $\begin{array}{l}0.6 \pm 0.02 \\
0.12 \pm 0.1\end{array}$ & $\begin{array}{l}\text { ND } \\
\text { ND }\end{array}$ \\
\hline \multicolumn{5}{|c|}{ Kidney } \\
\hline $\begin{array}{c}\text { Control } \\
\text { Experimental }\end{array}$ & $\begin{array}{c}7.4 \pm 0.2 \\
11.0 \pm 0.4\end{array}$ & $\begin{array}{c}8.7 \pm 0.9 \\
15.3 \pm 0.5\end{array}$ & $\begin{array}{l}5.1 \pm 0.7 \\
6.7 \pm 0.1\end{array}$ & $\begin{array}{l}16.7 \pm 2.8 \\
19.5 \pm 2.3\end{array}$ \\
\hline \multicolumn{5}{|c|}{ Skeletal muscle } \\
\hline $\begin{array}{c}\text { Control } \\
\text { Experimental }\end{array}$ & $\begin{array}{l}2.9 \pm 0.4 \\
3.1 \pm 0.8\end{array}$ & $\begin{array}{l}0.7 \pm 0.4 \\
1.0 \pm 0.4\end{array}$ & $\begin{array}{l}0.4 \pm 0.1 \\
0.3 \pm 0.1\end{array}$ & $\begin{array}{l}1.0 \pm 0.3 \\
3.2 \pm 0.9\end{array}$ \\
\hline
\end{tabular}

Total glutathione concentration in cells is usually denoted as 2GSSG + GSH, a significant amount of which may be bound to protein; GSH/GSSG is often used as an indicator of the cellular redox state and it is a major redox couple that determines the antioxidative capacity of cells, total cysteine concentration (2CSSC + Cys) determines the availability of cysteine to the glutathione biosynthesis; Cys/CSSC ratio is used as an indicator of the amount of free sulfhydryl group present in cysteine, which is crucial for the biological functions of proteins. ND: non-detectable. 


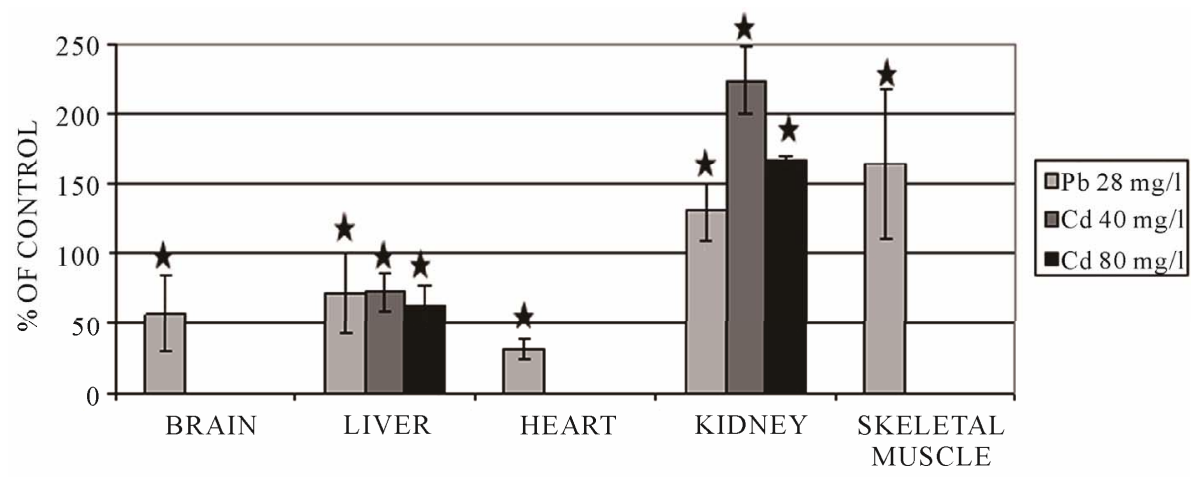

Figure 5. Changes of CST activity in frog tissues after 10-day exposure to heavy metal ions. " $p<0.05$.

Table 3. The effect of mercury on glutathione and cysteine levels in $X$. laevis (Standard deviations were not calculated because of a small number of measurements) [11].

\begin{tabular}{|c|c|c|c|c|}
\hline Group & $\begin{array}{l}\text { Total glutathione } \\
\text { nmol/mg protein }\end{array}$ & GSH/GSSG & $\begin{array}{l}\text { Total cysteine } \\
\text { nmol/mg protein }\end{array}$ & Cys/CSSC \\
\hline \multicolumn{5}{|c|}{ Brain } \\
\hline $\begin{array}{c}\text { Control } \\
\text { Experimental }\end{array}$ & 21 & 0.58 & ND & ND \\
\hline $\begin{array}{l}7 \text { days } \\
14 \text { davs }\end{array}$ & $\begin{array}{l}33 \\
25\end{array}$ & $\begin{array}{c}2.3 \\
0.34\end{array}$ & $\begin{array}{l}1.9 \\
\text { ND }\end{array}$ & $\begin{array}{c}14 \\
\text { ND }\end{array}$ \\
\hline \multicolumn{5}{|c|}{ Liver } \\
\hline $\begin{array}{c}\text { Control } \\
\text { Experimental }\end{array}$ & 18 & 11 & 1.5 & 0.24 \\
\hline $\begin{array}{l}7 \text { days } \\
14 \text { days }\end{array}$ & $\begin{array}{l}11 \\
14\end{array}$ & $\begin{array}{c}9 \\
13\end{array}$ & $\begin{array}{l}1.6 \\
2.1\end{array}$ & $\begin{array}{l}0.19 \\
0.33\end{array}$ \\
\hline \multicolumn{5}{|c|}{ Heart } \\
\hline $\begin{array}{c}\text { Control } \\
\text { Experimental }\end{array}$ & 8.3 & 19 & 0.10 & ND \\
\hline $\begin{array}{l}7 \text { days } \\
14 \text { days }\end{array}$ & $\begin{array}{c}0.98 \\
4.5\end{array}$ & $\begin{array}{l}7.8 \\
4.5\end{array}$ & $\begin{array}{l}0.20 \\
\text { ND }\end{array}$ & $\begin{array}{l}\text { ND } \\
\text { ND }\end{array}$ \\
\hline \multicolumn{5}{|c|}{ Kidney } \\
\hline $\begin{array}{c}\text { Control } \\
\text { Experimental }\end{array}$ & 37 & 56 & 1.4 & 3.2 \\
\hline $\begin{array}{l}7 \text { days } \\
14 \text { days }\end{array}$ & $\begin{array}{l}54 \\
46\end{array}$ & $\begin{array}{l}70 \\
17\end{array}$ & $\begin{array}{l}2.4 \\
2.8\end{array}$ & $\begin{array}{l}20 \\
6.7\end{array}$ \\
\hline \multicolumn{5}{|c|}{ Skeletal muscle } \\
\hline $\begin{array}{c}\text { Control } \\
\text { Experimental }\end{array}$ & 2.4 & 18 & 0.07 & 5.0 \\
\hline $\begin{array}{c}7 \text { days } \\
14 \text { days }\end{array}$ & $\begin{array}{l}0.2 \\
1.9\end{array}$ & $\begin{array}{l}8.0 \\
7.1\end{array}$ & $\begin{array}{c}0.1 \\
0.05\end{array}$ & $\begin{array}{l}\text { ND } \\
\text { ND }\end{array}$ \\
\hline
\end{tabular}

Total glutathione concentration in cells is usually denoted as 2GSSG + GSH, a significant amount of which may be bound to protein; GSH/GSSG is often used as an indicator of the cellular redox state and it is a major redox couple that determines the antioxidative capacity of cells, total cysteine concentration (2CSSC + Cys) determines the availability of cysteine to the glutathione biosynthesis; Cys/CSSC ratio is used as an indicator of the amount of free sulfhydryl group present in cysteine, which is crucial for the biological functions of proteins. ND: non-detectable.

\subsubsection{Liver}

The liver is the main tissue in which the synthesis of glutathione occurs and where heavy metal ions are detoxified [33]. GSH with bound heavy metal ions are excreted from the liver to the bile and then removed from the body [14]. In the presence of cadmium (Table 4) [8], an increased level of glutathione was observed, what may suggest its increased biosynthesis in response to cad- mium, which induces generation of reactive oxygen species $[34,35]$. However, in response to oxidative stress induced by lead and mercury, the concentration of cellular glutathione decreased significantly (Tables 2 and 3) $[11,12]$ in comparison with the control group, with the ratio of GSH/GSSG not significantly changed.

In the liver after exposition to all of the investigated ions, sulfane sulfur (Figure 2, Table 1) and cysteine levels 
Table 4. The effect of cadmium on glutathione and cysteine levels in $P$. ridibundus [8].

\begin{tabular}{|c|c|}
\hline Group & $\begin{array}{c}\text { Glutathione } \\
\text { nmol/mg protein }\end{array}$ \\
\hline \multicolumn{2}{|c|}{ Brain } \\
\hline $\begin{array}{c}\text { Control } \\
\text { Experimental } \\
40 \mathrm{mg} / \mathrm{L} \\
80 \mathrm{mg} / \mathrm{L}\end{array}$ & $\begin{array}{l}2.19 \pm 0.18 \\
2.87 \pm 0.18^{*} \\
2.56 \pm 0.33^{*}\end{array}$ \\
\hline \multicolumn{2}{|c|}{ Liver } \\
\hline $\begin{array}{c}\text { Control } \\
\text { Experimental } \\
40 \mathrm{mg} / \mathrm{L} \\
80 \mathrm{mg} / \mathrm{L}\end{array}$ & $\begin{array}{l}3.72 \pm 0.81 \\
6.08 \pm 0.99^{*} \\
6.68 \pm 1.66^{*}\end{array}$ \\
\hline \multicolumn{2}{|c|}{ Heart } \\
\hline $\begin{array}{c}\text { Control } \\
\text { Experimental } \\
40 \mathrm{mg} / \mathrm{L} \\
80 \mathrm{mg} / \mathrm{L}\end{array}$ & $\begin{array}{l}2.54 \pm 0.02 \\
2.47 \pm 0.07^{*} \\
1.81 \pm 0.05^{*}\end{array}$ \\
\hline \multicolumn{2}{|c|}{ Kidney } \\
\hline $\begin{array}{c}\text { Control } \\
\text { Experimental } \\
40 \mathrm{mg} / \mathrm{L} \\
80 \mathrm{mg} / \mathrm{L}\end{array}$ & $\begin{array}{l}0.29 \pm 0.01 \\
0.69 \pm 0.03^{*} \\
0.92 \pm 0.02^{*}\end{array}$ \\
\hline \multicolumn{2}{|c|}{ Skeletal muscle } \\
\hline $\begin{array}{c}\text { Control } \\
\text { Experimental } \\
40 \mathrm{mg} / \mathrm{L} \\
80 \mathrm{mg} / \mathrm{L}\end{array}$ & $\begin{array}{l}1.07 \pm 0.03 \\
0.59 \pm 0.01^{*} \\
0.49 \pm 0.02^{*}\end{array}$ \\
\hline
\end{tabular}

(Tables $\mathbf{2}$ and $\mathbf{3}$ ) were not significantly different from the control levels $[11,12]$. The availability of cysteine is a limiting factor of GSH synthesis [17].

As it is shown in Figures $\mathbf{4}$ and 5, in the liver, all metal ions caused a significant decrease of MPST and CST activity $[8,12]$. The decreased activity could be a result of binding and blocking of - $\mathrm{SH}$ groups in their active sites by heavy metal ions or their oxidation to $-\mathrm{SOH}$ in the presence of an increased concentration of reactive oxygen species. Similarly, the liver of frogs exposed to lead and mercury ions demonstrated a significantly lower activity of rhodanese (Figure $\mathbf{3}$ and Table 1) $[8,12]$. Only in the liver of the animals exposed to cadmium was the activity of rhodanese after 10 days of exposure elevated [8]. One cannot exclude the effect of heavy metal ions or the oxidative stress on the expression of the genes for the investigated enzymes.

\subsubsection{Heart}

In the heart, cadmium, lead and mercury decreased the activity of MPST and, in consequence, depleted sulfane sulfur levels (Figures 2 and 4) [8,11,12]. Additionally, lead also caused a diminished activity of CST in comparison with the control group (Figure 5) [12]. Figure 3 shows that in the heart, cadmium caused a slightly increased rhodanese activity [8]. The activity of rhodanese (Table 3) in the heart of frogs from the group exposed to mercury for 7 days was maintained on a comparable level with the control group, whereas this activity decreased by $75 \%$ in the animals exposed to mercury for 14 days [11]. Taking into account the function of the analyzed enzymes and binding of heavy metal ions with sulfhydryl groups of the active site of these enzymes [16], it may be a reason of decreasing activity of MPST and CST in the cells of the heart muscle after exposure to lead [12]. Deceleration of cysteine transformation through formation of sulfane sulfur-containing compounds can augment the amount of cysteine for synthesis of GSH (Table 2) [12]. Simultaneously, a double level of total glutathione and an increased ratio of GSH/GSSG were determined in the hearts of $P$. ridibundus exposed to lead $(28 \mathrm{mg} / \mathrm{l})$ as compared to the control group [12]. Contrary to lead, total glutathione, total cysteine and the ratio of GSH/GSSG decreased along with the time of exposure to mercury (Table 3) [11]. Similarly, cadmium caused depletion of glutathione levels in the heart muscle after 10 days (Table 4) [8]. These results suggested that the hearts of animals exposed to heavy metal ions activity had an effective antioxidative mechanism, which is reasonable in view of a fact that the heart has a completely oxygen-dependant metabolism.

\subsubsection{Kidney}

The kidney has a strong tendency to accumulate heavy metal ions (Figure 1) [11]. In P. ridibundus, cadmium accumulation in the kidney and liver was very high and appeared to be time-dependent [36]. Previous studies revealed that heavy metal ions caused histopathological and ultrastructural lesions in the kidney $[33,37,38]$.

In the kidneys, after exposure to cadmium, an increase of the activity of sulfurtransferases was observed (Figures 3-5) [8]. Similarly, in response to exposure to lead ions, a significant increase of the activity of CST was found in the kidney (Figure 5) [12]. This may suggest that in this tissue, intensive metabolism takes place, leading to the formation of cysteine from methionine and further conversion of cysteine to sulfane sulfur-containing compounds. The sulfane sulfur level did not change significantly in all the investigated protocols of exposure to cadmium and lead (Figure 2) [11,12]. After a 7-day-long exposure to mercury, the observed level of sulfane sulfur was comparable to the level determined in the control group, but in the frogs from the group exposed to mercury for 14 days, the sulfane sulfur level was significantly lower (Table 1) [11]. Moreover, contrary to the abovementioned results, the activities of sulfurtransferase in the kidneys of animals after exposure to mercury were significantly lower than in the controls (Table 1) [11]. 
Cells exposed to heavy metal ions have a greater demand for glutathione. It is known that the kidney exhibits a high activity of GGTP, the enzyme hydrolyzing GSH with the release of CysGly, and cysteinylglycine dipeptydase, the enzyme hydrolyzing this dipeptide to amino acids. Moreover, the kidney has practically an unlimited access to serum GSH and Cys because of a high activity of GGTP [26,39].

The fact that all the investigated metal ions cause an increase in GSH and Cys levels (Tables 2-4) [8,11,12] is probably related to defense against oxidative processes induced by the ions. As it is shown in Table 2, almost a double increase in total glutathione level and the ratio of GSH/GSSG in the kidneys can be observed. An increasing value of GSH/GSSG ratio, also in other cases (except $1.353 \mathrm{mg} \mathrm{Hg} / \mathrm{l} ; 14$ days) (Table 3) can suggest that in the kidneys of animals exposed to heavy metal ions intensive synthesis of Cys and GSH has occurred. In that tissue, also intensive transformation of sulfane sulfur-containing compounds by sulfurtransferases takes place [11].

These results indicate an increase in the level of enzymatic proteins in the cells of the kidney (cadmium, lead) e.g. in response to oxidative stress [13] and this can confirm the participation of sulfurtransferases in antioxidative protection in the kidneys. After heavy metal ions have entered the body, they are bound with protein having - $\mathrm{SH}$ group in their active site or there are formed complexes with low-molecular-weight thiols such as GSH or metallothioneines [40]. In order to eliminate these complexes, they have to be transported to the kidney, where free heavy metal ions are released and absorbed in the proximal tubes [41]. If the levels of antioxidants and metallothioneines are too low, then the tissue is going to be damaged [41]. The results obtained for mercury ions confirmed that observation.

\subsubsection{Skeletal Muscle}

In the skeletal muscle, the ratio of GSH/GSSG decreased along with the time of exposure to mercury (Table 3) [11] in comparison with the controls. Similarly, after cadmium exposure, the level of GSH was decreased-the effect was dose-dependent (Table 4) [8]. In the skeletal muscle, in turn, total GSH and Cys levels and the ratio of GSH/GSSG in response to lead ions remained unchanged (Table 2) [12]. The activity of rhodanese (Figure 3 and Table 1) and MPST (Figure 4 and Table 1) after cadmium, lead and mercury exposure was depleted $[8,11,12]$. In the skeletal muscle, after 14 days of exposure to mercury, a twofold decrease of CST activity was observed (Table 1) [11]. In contrast, lead ions caused an increase of CST activity (Figure 5) [12]. As it is shown in Figure 2 and Table 1, sulfane sulfur levels in animals exposed to cadmium and mercury for 7 days are increased, but after long-term exposure to mercury and lead, these lev- els are decreased $[8,11,12]$. The differences suggest that the skeletal muscle utilizes Cys to synthesize sulfane sulfur-containing compounds, but after longer exposure times, sulfane sulfur level is decreased because of a reduced activity of sulfurtransferases; this can be caused by binding heavy metal ions, accumulating in this tissue, by - $\mathrm{SH}$ groups in their active sites.

Skeletal muscle tissue is not strictly dependent on aerobic metabolism. This can be a reason of a quite low level of GSH in the muscle (only $30 \%$ of the value assayed for the liver (Table 4)) [8].

\section{Conclusions}

Summarizing the results of this work, heavy metal ions can interfere with and disturb a variety of processes in cells by, among others, changing the activity of sulfurtransferases in such tissues as the brain, liver, heart, skeletal muscle and kidney $[8,11,12]$.

Lead ions resulted in decreasing the activity of all the investigated enzymes in the liver, in the heart except MPST (no change), in the skeletal muscle rhodanese (MPST without any change) and in the brain CST. At the same time, the brain demonstrated an increased activity of rhodanese and MPST and the kidney and skeletal muscle-an increased CST activity [12].

Cadmium ions resulted in decreasing the activity of rhodanese in the skeletal muscle, MPST in heart and skeletal muscle and CST in the liver. On the other hand, an increased activity of rhodanese was observed in the brain, liver, heart and kidney and increased MPST and CST activity in the kidney [8].

Mercury ions affected a decrease in rhodanese activity in all the investigated tissues, in MPST activity - in all the tissues except liver and skeletal muscle, and in CST activity - in the kidney (the levels were unchanged in the remaining tissues) [11].

In response to mercury ions, in all the tissues the level of sulfane sulfur decreased, while in response to exposure to cadmium ions, a decrease was observed solely in the heart and in the case of lead ions - in the brain, heart and skeletal muscle. The level of sulfane sulfur in the liver and kidney was maintained stable both in case of exposure to cadmium and lead ions $[8,11,12]$.

Lead ions resulted in decreasing glutathione levels in the brain [12], cadmium ions - in the heart and skeletal muscle [8] and mercury ions - in the liver, heart and skeletal muscle [11]. On the other hand, the authors also observed an increased level of glutathione in the heart and kidney (lead ions), brain, liver and kidney (cadmium ions) as well as in the brain and kidney exposed to mercury ions.

A decreased activity of the investigated enzymes may occur in consequence of heavy metal ions binding to 
$-\mathrm{SH}$ groups in their active sites. Another cause may lie in oxidation of the groups to $-\mathrm{SOH}$ in case the level of reactive oxygen species increases, what may happen in tissues with depleted glutathione levels [16].

The present results also suggest altered gene expression and enzyme protein levels. The suggestion requires confirmation; it would be also worthwhile to assess whether changes in these protein levels are a response to heavy metal ions or rather to oxidative stress. It has been observed that heavy metal ions cause depression of GSH/ GSSG ratio. This would support the role of sulfurtransferases in defenses against reactive oxygen species [42, $43]$ and their antioxidant and anti-cancer activity $[44,45]$.

\section{REFERENCES}

[1] D. Quig, "Cysteine Metabolism and Metal Toxicity," Alternative Medicine Review, Vol. 4, No. 3, 1998, pp. 262269.

[2] T. W. Clarkson, "The Three Modern Faces of Mercury," Environmental Health Perspectives, Vol. 110, No. S1, 2002, pp. 11-23. doi:10.1289/ehp.02110s111

[3] L. Patric, "Lead Toxicity Part II: The Role of Free Radical Damage and the Use of Antioxidants in Pathology and Threatment of Lead Toxicity," Alternative Medicine Review, Vol. 11, No. 2, 2006, pp. 114-127.

[4] J. P. K. Rooney, "The Role of Thiols, Dithiols, Nutritional Factors and Interacting Ligands in the Toxicology of Mercury," Toxicology, Vol. 234, No. 3, 2007, pp. 145156. doi:10.1016/j.tox.2007.02.016

[5] S. S. Sharma and K. J. Dietz, "The Relationship between Metal Toxicity and Cellular Redox Imbalance," Trends in Plant Science, Vol. 14, No. 1, 2009, pp. 43-50. doi:10.1016/j.tplants.2008.10.007

[6] H. Needleman, "Lead Poisoning," Annual Review of Medicine, Vol. 55, 2004, pp. 209-222. doi:10.1146/annurev.med.55.091902.103653

[7] J. P. Bressler and G. W. Goldstein, "Mechanism of Lead Neurotoxicity," Biochemical Pharmacology, Vol. 41, No. 4, 1991, pp. 479-484. doi:10.1016/0006-2952(91)90617-E

[8] P. Sura, N. Ristic, P. Bronowicka and M. Wróbel, "Cadmium Toxicity Related to Cysteine Metabolism and Glutathione Levels in Frog Rana ridibunda Tissues," Comparative Biochemistry and Physiology, Vol. 142C, No. 1-2, 2006, pp. 128-135.

[9] P. Sura, M. Wróbel and P. Bronowicka, "Season Dependent Response of the Marsh Frog (Rana ridibunda) to Cadmium Exposure," Folia Biologica (Kraków), Vol. 54, No. 3-4, 2006, pp. 159-165. doi:10.3409/173491606778557536

[10] M. A. Lynes, Y. J. Kang, S. L. Sensi, G. A. Perdrizet and L. E. Hightower, "Heavy Metal Ions in Normal Physiology, Toxic Stress and Cytoprotection," Annals of the New York Academy of Science, Vol. 1113, 2007, pp. 159-172. doi:10.1196/annals.1391.010

[11] P. Sura, P. Bronowicka-Adamska, E. Furtak and M. Wró- bel, "Effect of Mercury Ions on Cysteine Metabolism in Xenopus laevis Tissues," Comparative Biochemistry and Physiology, Vol. 154C, No. 3, 2011, pp. 180-186.

[12] M. Kaczor, P. Sura, P. Bronowicka-Adamska and M. Wróbel, "Exposition to Lead in Water and Cysteine Metabolism in Pelophylax ridibundus Tissues," Aquatic Toxicology, Vol. 127, 2013, pp. 72-77. doi:10.1016/j.aquatox.2012.03.014

[13] S. J. Flora, M. Mittal and A. Metha, "Heavy Metal Induced Oxidative Stress \& Its Possible Reversal by Chelation Therapy," Indian Journal of Medical Research, Vol. 128, No. 4, 2008, pp. 501-523.

[14] M. Valko, H. Morris and M. T. D. Cronin, "Metals, Toxicity and Oxidative Stress," Current Medicinal Chemistry, Vol. 12, No. 10, 2005, pp. 1161-1208. doi:10.2174/0929867053764635

[15] T. L. Guidotti and L. Ragain, "Protecting Children from Toxic Exposure: Three Strategies," Pediatric Clinic of North America, Vol. 54, No. 2, 2007, pp. 227-235. doi:10.1016/j.pcl.2007.02.002

[16] N. Nagahara, "Catalytic Site Cysteine of Thiol Enzyme, Sulfurtransferase," Journal of Amino Acids, Vol. 2011, 2011, pp. 1-7. doi:10.4061/2011/709404

[17] S. Mani, G. Yang and R. Wang, "A Critical Life-Supporting Role for Cystathionine $\gamma$-Lyase in the Absence of Dietary Cysteine Supply," Free Radical Biology and Medicine, Vol. 50, No. 10, 2011, pp. 1280-1287. doi:10.1016/j.freeradbiomed.2011.01.038

[18] J. I. Toohey, "Sulphane Sulfur in Biological Systems: A Possible Regulatory Role," Biochemistry, Vol. 264, No. 3, 1989, pp. 625-632.

[19] W. N. Valentine and J. K. Frankenfeld, "3-Mercaptopyruvate Sulfur Transferase (EC: 2.8.1.2.): A Simple Assay Adapted to Human Blood Cells," Clinica Chimica Acta, Vol. 51, No. 2, 1974, pp. 205-210. doi:10.1016/0009-8981(74)90031-X

[20] M. Wróbel, H. Jurkowska, L. Śliwa and Z. Srebro, "Sulfurtransferases and Cyanide Detoxification in Mouse Liver, Kidney and Brain," Toxicology Mechanisms and Methods, Vol. 14, No. 6, 2004, pp. 331-337. doi:10.1080/15376520490434683

[21] B. Sörbo, "Rhodanase. Methods in Enzymology, (Colowick SP, Kaplan NO, eds.)," Academic Press, New York, Vol. 2, 1955, pp. 334-337. doi:10.1016/S0076-6879(55)02207-6

[22] Y. Matsuo and D. M. Greenberg, "A Crystalline Enzyme That Cleaves Homoserine and Cystathionine," The Journal of Biological Chemistry, Vol. 230, No. 2, 1958, pp. 545-560.

[23] J. Czubak, M. Wróbel and H. Jurkowska, "Cystathionine $\gamma$-Lyase (EC: 4.4.1.1.) an Enzymatic Assay of $\alpha$-Ketobutyrate Using Lacetate Dehydrogenase," Acta Biological Cracoviensia Series Zoologica, Vol. 44, 2002, pp. 113117.

[24] J. L. Wood, "Sulfane Sulfur," In: W. W. Jakoby and O. W. Griffith, Eds., Methods in Enzymology, Academic Press, San Diego, 1987, pp. 25-29.

[25] O. H. Lowry, N. J. Rosenbrough, A. L. Farr and R. I. Ran- 
dall, "Protein Measurement with the Folin Phenol Reagent," The Journal of Biological Chemistry, Vol. 193, No. 1, 1951, pp. 265-275.

[26] P. K. Dominick, P. B. Cassidy and J. C. Roberts, "A New and Versatile Method for Determination of Thiolamines of Biological Importance," Journal of Chromatography B: Biomedical Sciences and Applications, Vol. 761, No. 1, 2001, pp. 1-12. doi:10.1016/S0378-4347(01)00298-5

[27] M. Wróbel, I. Lewandowska, P. Bronowicka-Adamska and A. Paszewski, "Sulfurtransferases and Cyanide Detoxification in Mouse Liver, Kidney and Brain," Toxicology Mechanisms and Methods, Vol. 14, No. 6, 2009, pp. 331-337. doi:10.1080/15376520490434683

[28] M. Szczerbowska-Boruchowska, "X-Ray Fluorescence Spectrometry, an Analytical Tool in Neurochemical Research," X-Ray Spectromery, Vol. 37, No. 1, 2008, pp. 21-31. doi:10.1002/xrs. 1007

[29] R. Dringen, J. M. Gutterer and J. Hirrlinger, "Glutathione Metabolism in Brain. Metabolic Interaction between Astrocytes and Neurons in the Defence against Reactive Oxygen Species," European Journal of Biochemistry, Vol. 267, No. 16, 2000, pp. 4912-4916. doi:10.1046/j.1432-1327.2000.01597.x

[30] J. B. Schulz, J. Lindenau, J. Seyfried and J. Dichgans, "Glutathione, Oxidative Stress and Neurodegeneration," European Journal of Biochemistry, Vol. 267, No. 16, 2000, pp. 4904-4911. doi:10.1046/j.1432-1327.2000.01595.x

[31] Y. Ogasawara, S. Isoda and S. Tanabe, "A Labile Sulfur in Trisulfide Affects Cytochrome P-450 Dependnet Lipid Peroxidation in the Rat Liver Microsomes," Toxicology Letters, Vol. 99, No. 3, 1998, pp. 191-198. doi:10.1016/S0378-4274(98)00156-8

[32] D. K. Rassin, "Source, Metabolism, and Function of Cysteine and Glutathione in the Central Nervous System," Journal of Nauroscience Methods, Vol. 30, 1996, pp. 167-177. doi:10.1016/S1043-9471(96)80103-0

[33] S. M. A. El-Shenawy and N. S. Hassan, "Comparative Evaluation of the Protective Effect of Selenium and Garlic against Liver and Kidney Damage Induced by Mercury Chloride in the Rats," Pharmacological Reports, Vol. 60, No. 2, 2008, pp. 199-208.

[34] A. Pompella, A. Visvikis, A. Paolicchi, V. De Tata, A. F. Casini, "The Changing Faces of Glutathione, a Cellular Protagonist," Biochemical Pharmacology, Vol. 66, No. 8, 2003, pp. 1499-1503. doi:10.1016/S0006-2952(03)00504-5

[35] Y. Wang, J. Fang, S. S. Leonard and K. M. Krishna Rao, "Cadmium Inhibits the Electron Transfer Chain and Induces Reactive Oxygen Species," Free Radical Biology and Medicine, Vol. 36, No. 11, 2004, pp. 1434-1443. doi:10.1016/j.freeradbiomed.2004.03.010

[36] A. K. Vogiatzis and N. S. Loumbourdis, "Cadmium Accumulation in Liver and Kidneys and Hepatic Metallothionein and Glutathione Levels in Rana ridibunda, after exposure to $\mathrm{CdCl}_{2}$," Archives Environmental Contamination and Toxicolgy, Vol. 34, No. 1, 1998, pp. 64-68. doi: $10.1007 / \mathrm{s} 002449900286$

[37] A. Stacchiotti, E. Borsani, L. Rodella, R. Rezzani, L. Bianchi and A. Lavaza, "Dose-Dependent Mercuric Chloridemtubular Injury in Rat Kidney," Ultrastructural Pathology, Vol. 27, No. 4, 2003, pp. 253-259. doi:10.1080/01913120309921

[38] A. Stacchiotti, A. Lavaza, R. Rezzani, E. Borsani, L. Rodella and L. Bianchi, "Mercuric Chloride-Induced Alterations in Stress Protein Distribution in Rat Kidney," Histology and Histopathology, Vol. 19, No. 4, 2004, pp. 1209-1218.

[39] L. H. Lash, "Glutathione Transport in the Kidneys. Experimental Models, Mechanisms, and Methods," Methods in Pharmacology and Toxicology, Vol. 3, 2005, pp. 319339.

[40] G. Wu, Y-Z. Fang, S. Yang, J. R. Lupton and N. D. Turner, "Glutathione Metabolism and Its Implication for Health," The Journal of Nutrition, Vol. 134, No. 3, 2004, pp. 489-492.

[41] P. Manna, M. Sinha and P. C. Sil, "Taurine Plays a Beneficial Role against Cadmium-Induced Oxidative Renal Dysfunction," Amino Acids, Vol. 36, No. 3, 2009, pp. 417-428. doi:10.1007/s00726-008-0094-x

[42] Y. Ogasawara, G. M. Lacourciere, K. Ishii and T. C. Stadtman, "Characterization of Potential Selenium-Binding Proteins in the Selenophosphate Synthetase System," Proceedings of the National Academy of Science, Vol. 102, No. 4, 2005, pp. 1012-1016. doi:10.1073/pnas.0409042102

[43] M. Wróbel and H. Jurkowska, "Menadione Effect on L-Cysteine Desulfuration in U373 Cells," Acta Biochimica Polonica, Vol. 54, No. 2, 2007, pp. 407-411.

[44] J. T. Pinto, B. F. Krasnikov and A. J. L. Cooper, "RedoxSensitive Proteins Are Potential Targets of Garlic-Derived Mercaptocysteine Derivatives," Journal of Nutrition, Vol. 136, Suppl. 3, 2006, pp. 835S-841S.

[45] R. Sabelli, E. Iorio, A. De Martino, F. Podo, A. Ricci, G. Viticchiè, G. Rotilio, M. Paci and S. Melino, "RhodaneseThioredoxin System and Allyl Sulfur Compounds," FEBS Journal, Vol. 275, No. 15, 2008, pp. 3884-3899. doi:10.1111/j.1742-4658.2008.06535.x

\author{
Abbreviations \\ CST: $\gamma$-cystathionase; \\ GSH: reduced glutathione; \\ GSSG: oxidized glutathione; \\ GGTP: $\gamma$-gluthamyltranspeptidase;
}

MPST: 3-mercaptopyruvate sulfurtransferase;

Cys: cysteine;

CSSC: cystine;

ROS: reactive oxygen species. 